\title{
Root to branch wood anatomical variation and its influence on hydraulic conductivity in five Brazilian Cerrado species
}

\author{
Variación anatómica de madera desde la raíz a la rama y su influencia \\ en la conductividad hidráulica en cinco especies de Cerrado brasileño
}

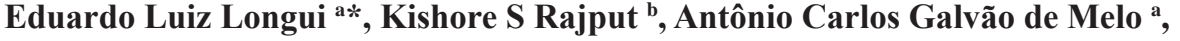 \\ Laura de Araújo Alves a, Caroline Bianca do Nascimento ${ }^{\text {a }}$

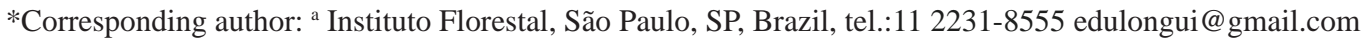 \\ b The Maharaja Sayajirao University of Baroda, Department of Botany, Faculty of Science, Vadodara, India.
}

\begin{abstract}
SUMMARY
The wood anatomy of the root, stem (base, middle, top) and branch of Anadenanthera peregrina, Copaifera langsdorffii, Handroanthus ochraceus, Ocotea corymbosa and Xylopia aromatica growing naturally in the Brazilian Cerrado is investigated. The important findings are correlated with hydraulic architecture and mechanical requirements. The presence of hydraulic bottlenecks (also referred to as hydraulic constrictions) is evident in the transition from root to stem, but no such transition is observed from stem to branch in other four species except for Xylopia aromatica. Compared with solitary vessels, proportion of multiple vessels is higher in the roots of Anadenanthera peregrina and Copaifera langsdorffii, as well as in the roots and stem-base of Xylopia aromatica indicating a tendency toward higher safety of roots from embolism as compared to the stem. Dimensions of rays, fibers and dry biomass percentage did not clearly show variations in these cells to influence the mechanical strength. Besides reducing hydraulic conductivity, decrease in vessel diameter from the root to the stem base may also impact mechanical strength by reducing empty spaces (vessel lumen). We concluded that the wood of the stem base of the species investigated shows mechanism to safeguard from air embolism by producing narrower vessels, which can protect the main stem from constant loss of conductivity.
\end{abstract}

Key words: ecological anatomy, hydraulic conductivity, tropical woods, wood axial variation.

\section{RESUMEN}

Se investigó la anatomía de la madera de la raíz, el tronco (base, medio, superior) y la rama de Anadenanthera peregrina, Copaifera langsdorffi, Handroanthus ochraceus, Ocotea corymbosa, Xylopia aromatica que crece naturalmente en el Cerrado brasileño. Los principales resultados se correlacionan con la arquitectura hidráulica y requerimientos mecánicos. La presencia de estrangulamientos hidráulicos (también conocidos como constricciones de flujo) son evidentes en la transición desde la raíz a tronco, pero no hay tal transición desde el tronco hasta la rama en otras cuatro especies, excepto Xylopia aromatica. En comparación con los vasos solitarios, la proporción de múltiples vasos es mayor en las raíces de Anadenanthera peregrina y Copaifera langsdorffii, así como las raíces y base del tronco de Xylopia aromatica parecen indicar una tendencia hacia una mayor seguridad de las raíces a la embolia en comparación con el tronco. Las dimensiones de los radios, las fibras y el porcentaje de biomasa seca no mostraron claramente variaciones de estas células para influir en la resistencia mecánica. Además de reducir la permeabilidad, la disminución en el diámetro del vaso de la raíz a la base del tronco, también puede afectar a la resistencia mecánica mediante la reducción de espacios vacíos (luz del vaso). Se concluyó que la madera de la base del tronco de las especies estudiadas es menos susceptible al desarrollo de burbujas de aire debido a la producción de los vasos más estrechos, que pueden proteger el tronco principal de la pérdida constante de conductividad.

Palabras clave: anatomía ecológica, conductividad hidráulica, maderas tropicales, variación axial en la madera.

\section{INTRODUCTION}

Wood provides essential functions such as mechanical support and ascent of sap, and acts as reservoir for water, starch and other substances (Sperry et al. 2006). To understand how plants optimize these competing functions, it is important to investigate the structural heterogeneity of wood that is responsible for spatial variation in the hydraulic and mechanical performance of the secondary xylem (Gartner and Meinzer 2005). The analysis from root to tree top xylem anatomy could help in understanding tree hydraulic architecture. It reflects the efficiency and safety of water conductivity and is regulated in part by anatomical features, such as the arrangement, frequency, length of vessels and its diameter, wall thickness and pit characteristics of the conducting cells (Sperry et al. 2006, Choat et al. 2008). 
Structural differences between the root and stem wood have been correlated with different functions and environmental pressures that affect both organs (Machado et al. 2007). Gasson (1987) compared root and stem anatomy of Quercus robur L. and reported no variation in vessel diameter between the root and the stem collected at a height of $1.30 \mathrm{~m}$ above ground (DBH). Generally in trees, vessels tend to have larger diameter in roots than in stems. Lower vessel frequency in roots compared with the stems, and wider rays in the roots are recorded in Cerrado (Brazilian savannah) species (Machado et al. 2007). Available literature indicates that roots of Lippia salviifolia have longer fibers with wider diameter (Goulart and Marcati 2008), while in Quercus robur fibers are longer and relatively thick-walled in the root but no variation was observed in the diameter of fibers of stem (Gasson 1987).

The anatomical differences between root and stem of trees growing in temperate and other tropical climates have been extensively studied and described by several authors, but Cerrado forest type is unique and no much information is available on the stem and root anatomy of species occurring in this forest type (Machado et al. 2007, Palhares et al. 2007, Goulart and Marcati 2008). Moreover, this area is prone to forest fires, tree species habit is relatively dwarf as compared with same species growing in other forest types and content of aluminum in soil is also higher in this forest type (Oliveira-Filho and Ratter 2002). Therefore, studies on hydraulic architecture of plants growing in such forest area will help us in better understanding the adaptability of plants growing in this unique forest.

Recent studies have shown an axial widening of the vessel elements from the stem apex to base of trees, and reported that change in vessels diameter in xylem architecture is crucial for trees growth to maintain the hydraulic efficiency and protect the vessel from embolism (Olson and Rosell 2013, Petit and Crivellaro 2014).

Therefore, in the present study we investigate anatomical variations between the root and stem of native Brazilian species in order to expand knowledge about axial transport of water and mechanical requirements of tree species growing in this unique habitat. In this context we investigated wood anatomy of the root, stem (base, middle and top) and branch of five species (viz. Anadenanthera peregrina, Copaifera langsdorffi, Handroanthus ochraceus (Chamisso) J.R. Mattos, Ocotea corymbosa (Meisn.) Mez and Xylopia aromatica (Lam.) Mart.) growing naturally in the Cerrado area of the São Paulo state, Brazil.

We tested the hypothesis that there is a pattern in hydraulic architecture of xylem towards root-branch trees, regardless of species, to optimize the potential of water conductivity. Our goal is to determine wood and dry biomass axial variations from root to branch in these five species and to discuss the results in the context of hydraulic architecture and mechanical requirements.

\section{METHODS}

Collection of samples. Samples from 22 young trees of five species of age group 5 to 10 years were collected from Anadenanthera peregrina $(\mathrm{n}=3)$, Copaifera langsdorffii $(\mathrm{n}=5)$, Handroanthus ochraceus $(\mathrm{n}=5)$, Ocotea corymbosa $(\mathrm{n}=5)$ and Xylopia aromatica $(\mathrm{n}=4)$.

For collection of samples, trees were identified by measuring their height and stem diameter at breast height. Selected trees were up rooted to obtain roots samples about $20 \mathrm{~cm}$ deep from the main sinker root. Stem samples were obtained at three different heights i.e. from the base (10 $\mathrm{cm}$ above ground, named S1), middle of the stem (S2) and stem top (S3); while samples from the roots were obtained from only one location i.e. $20 \mathrm{~cm}$ deep from the ground level). The height in meters varied according to tree height, and samples of the first branch of the stem were also collected (figure 1 and table 1), samples diameter in all positions ranged from $6 \mathrm{~cm}$ (root or stem base) to $1 \mathrm{~cm}$ (branches). For standardization, we studied wood anatomy of portion adjacent to the cambium. Samples were cut 1.5 $\mathrm{cm}^{3}$ on each disc, with the exception of the branches whose dimensions were less than $1 \mathrm{~cm}$; in the latter, samples consisted of the entire disk.

Estimation of dry biomass. Samples from roots (all roots with diameter $\geq 1 \mathrm{~cm}$ ), stem (material from soil until the first branch) and branches (branches with diameter $\geq 1$ $\mathrm{cm}$ ) were weighed immediately after the tree was cut or uprooted. Every sample was labeled and weighed on field with analytical balance and taken to the laboratory. After arriving to the laboratory, the samples were air dried for seven days. Subsequently, they were oven dried at $80^{\circ} \mathrm{C}$ until constant weight was achieved.

Anatomical analyses. Small pieces wood samples adjacent to the cambium were cut from the wood disk and used for sectioning in various plains (such as transverse, radial and tangential longitudinal) and for the macerations. Prior to the sectioning, wood samples were boiled for about 60-90

Table 1. Dendrometric data of five Brazilian Cerrado species ( 5 to 10 years old).

Datos dendrométricos de cinco especies de Cerrado (5-10 años).

\begin{tabular}{lcc}
\hline \multicolumn{1}{c}{ Species } & $\begin{array}{c}\text { Average height } \\
(\mathrm{m})\end{array}$ & $\begin{array}{c}\text { Average DBH } \\
(\mathrm{cm})\end{array}$ \\
\hline Anadenanthera peregrina & 3.4 & 5.6 \\
Copaifera langsdorffi & 3.9 & 4.5 \\
Handroanthus ochraceus & 2.9 & 4.3 \\
Ocotea corymbosa & 4.0 & 4.0 \\
Xylopia aromatica & 4.2 & 4.8 \\
\hline
\end{tabular}


min in water, glycerin and alcohol (4:1:1), and sections of 16-20 $\mu \mathrm{m}$ thickness were cut with the help of sledge microtome. Sections were stained with a $1 \%$ solution of aqueous safranin, washed with distilled water and mounted in a solution of water and glycerin (1:1) on slides. For maceration, thin slices were prepared from the wood portion adjacent to the bark and treated with the modified Franklin's method (equal part of: glacial acetic acid $+30 \%$ hydrogen peroxide) at $40-45{ }^{\circ} \mathrm{C}$ for 24 to $36 \mathrm{~h}$. Macerated wood slices were washed thoroughly in water and stained with $1 \%$ aqueous solution of safranin. Temporary slides were prepared in $1 \%$ glycerin. Slides were subsequently observed under Olympus CX 31 research microscope and important results were micro-photographed with a digital camera (Olympus Evolt E330). Measurements were carried out using image analyzer software (Image-Pro 6.3). Terminology and wood descriptions are followed as described in the IAWA list (IAWA 1989), at least 25 measure- ments were taken on each feature. Pit was the exception, in which 10 measurements were taken.

Hydraulic conductivity was calculated based on vessel diameter using the following equation [1]:

$$
\mathrm{K}_{\mathrm{h}}=\pi \mathrm{D}^{4} / 128 \eta \text {, }
$$

where $\mathrm{D}=$ diameter and $\eta=$ viscosity index of water $\left(1.002 \times 10^{-9} \mathrm{MPa}\right.$ s at $\left.20^{\circ} \mathrm{C}\right) . \mathrm{K}_{\mathrm{h}}=$ hydraulic conductivity (Scholz et al. 2013).

Statistical analyses. We initially performed descriptive statistical analyses and comparisons between means and standard deviations to test the differences among the groups (wood samples in different heights). On the basis of these results, we employed the "t-test sample size" to determine the number of measurements to the power of 0.8. Based on the normal distribution of data, a parametric analysis
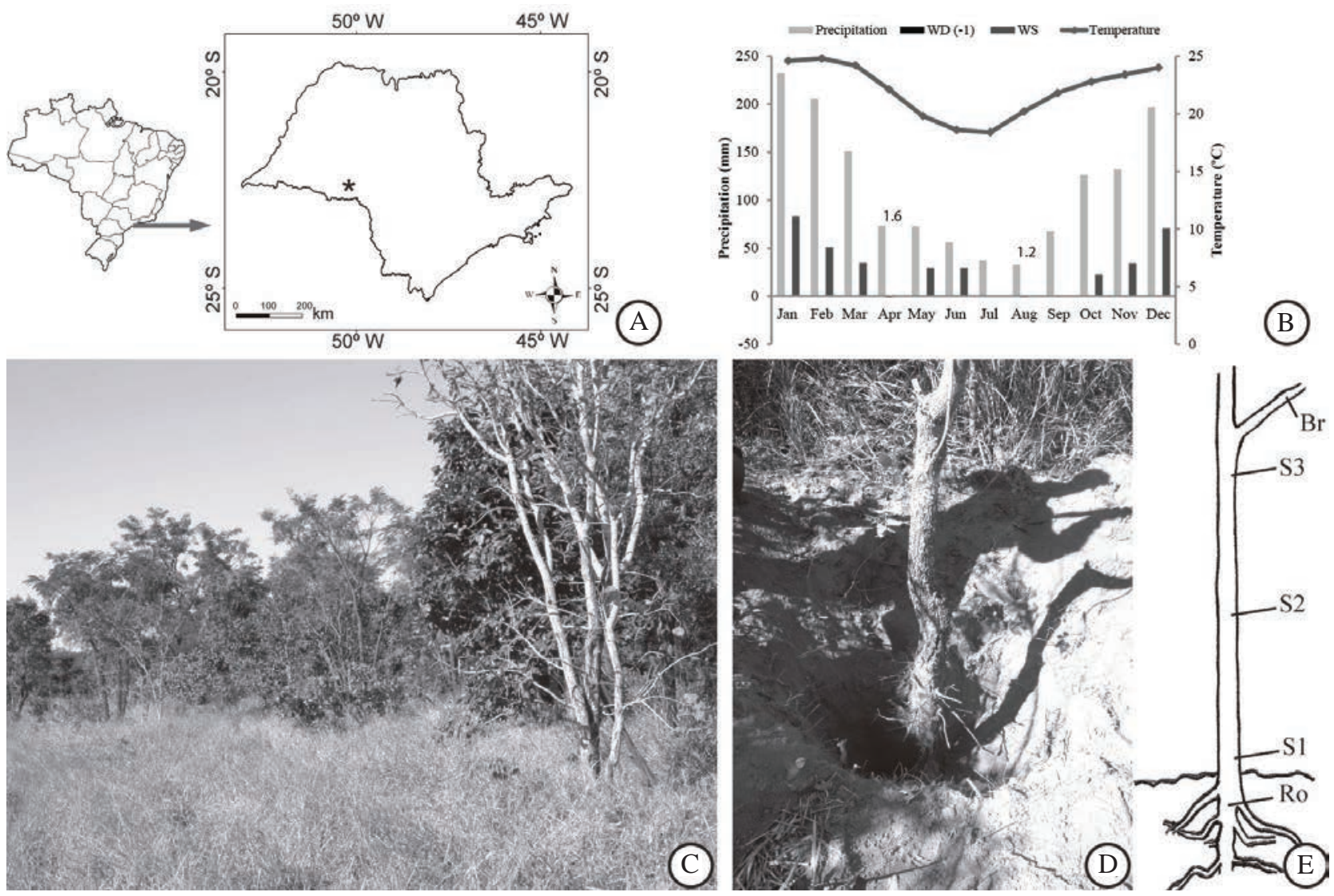

Figure 1. A) Location of Assis State Forest (*) in São Paulo State, Brazil. B) Mean monthly precipitation, water deficit WD (-1), water surplus WS and mean temperature (lines) at Assis State Forest - 1961-1990 (CEPAGRI 2015). C) Overview of the collection area. D) Tree being removed from soil. E) Schematic illustration of cutting samples for anatomical investigation. Abbreviations: Ro = root, S1 = Stem base, S2 = Middle of the stem, S3 = Stem top and Br. = Branch.

A) Localización del bosque estatal de Assis (*) en São Paulo, Brasil. B) Media de la precipitación mensual, déficit hídrico WD (-1), excedente hídrico WS y media de temperatura (líneas) en el Bosque estatal de Assis - 1961-1990 (CEPAGRI 2015). C) Descripción general del área de recolección. D) Árbol siendo retirado de suelo. E) Ilustración esquemática de corte de muestras para investigación anatómica. Abreviaturas: Ro = raíz, S1 = Base del tronco, S2 = Medio del tronco, S3 = Parte superior del tronco y Br. = Rama. 
of variance (one way analysis of variance) was performed using Sigma Plot 10.0 software to compare each anatomical feature. In case of a significant difference, Tukey test was applied to identify pairwise determinants of differences. Results with $P<0.01$ were considered as significant. We performed Pearson correlation among hydraulic conductivity and dry biomass with anatomical features.

Experimental area. As shown in figure 1, the study was carried out in the Cerrado area of the Assis State Forest $\left(22^{\circ} 34^{\prime} 19^{\prime \prime} \mathrm{S}, 50^{\circ} 23^{\prime} 32^{\prime \prime} \mathrm{W}\right.$ and altitude of $\left.588 \mathrm{~m}\right)$, Assis, São Paulo State (Brazil). The soil in this region has low organic matter, although it has good water permeability. The climate is Cwa by the Köppen climate classification, warm with dry winters, with mean annual temperature of 20-25 ${ }^{\circ} \mathrm{C}$ (with average minimum temperature of $18{ }^{\circ} \mathrm{C}$ ). The average annual rainfall is $1,441.5 \mathrm{~mm}$ (CEPAGRI 2015). The region has a dry season between April and September, and water deficit in April is -1.6, and in August it is -1.2 (figure 1).

\section{RESULTS}

The anatomical investigation showed that vessel diameter decreased significantly from the root tip towards the stem base in all five species, except in $H$. ochraceus, where the vessel diameters did not show much variation and were found to be more or less the same at the stem base (figure $2 \mathrm{~A}$ and figure $3 \mathrm{C}, \mathrm{D})$. Vessel diameter increased gradually from the stem base up to the middle of stem and gets stabilized up to stem top (S3). Thereafter, vessel diameter did not differ from the stem top to the branch in all five species (figure 2A). Vessel diameter varies among the species, but in general terms lower vessel diameter occurs in the stem base of A. peregrina, C. langsdorffii, $O$. corymbosa and $X$. aromatica (figure $2 \mathrm{~A}$ ).

Vessel frequency did not vary from the root to the stem base in all five species, nonetheless an increase in vessel frequency was observed from S3 to the branch, which did show a higher value in all five species. Vessel frequency varied among species without any observable pattern from the root to branches (figure 2B). Depending on the species, inter-vessel pit aperture also showed variations in size. A. peregrina and $H$. ochraceus did not show any variation, nevertheless narrowing of pit aperture size was observed from S2 to the branch in C. langsdorffii and from the root to the stem base in Ocotea corymbosa (figure 2C).

Hydraulic conductivity decreased from the root to the stem base in all the species investigated, except for $X$. aromatica (figure 2D). Contradictory results were found in aerial parts, depending on the species: A. peregrina and C. langsdorffii did not vary axially, whereas in H. ochraceus, hydraulic conductivity increased toward the branch, $O$. corymbosa showed oscillation, and in X. aromatica, hydraulic conductivity increased toward the top of the stem, although it decreased to the branch (figure 2D).

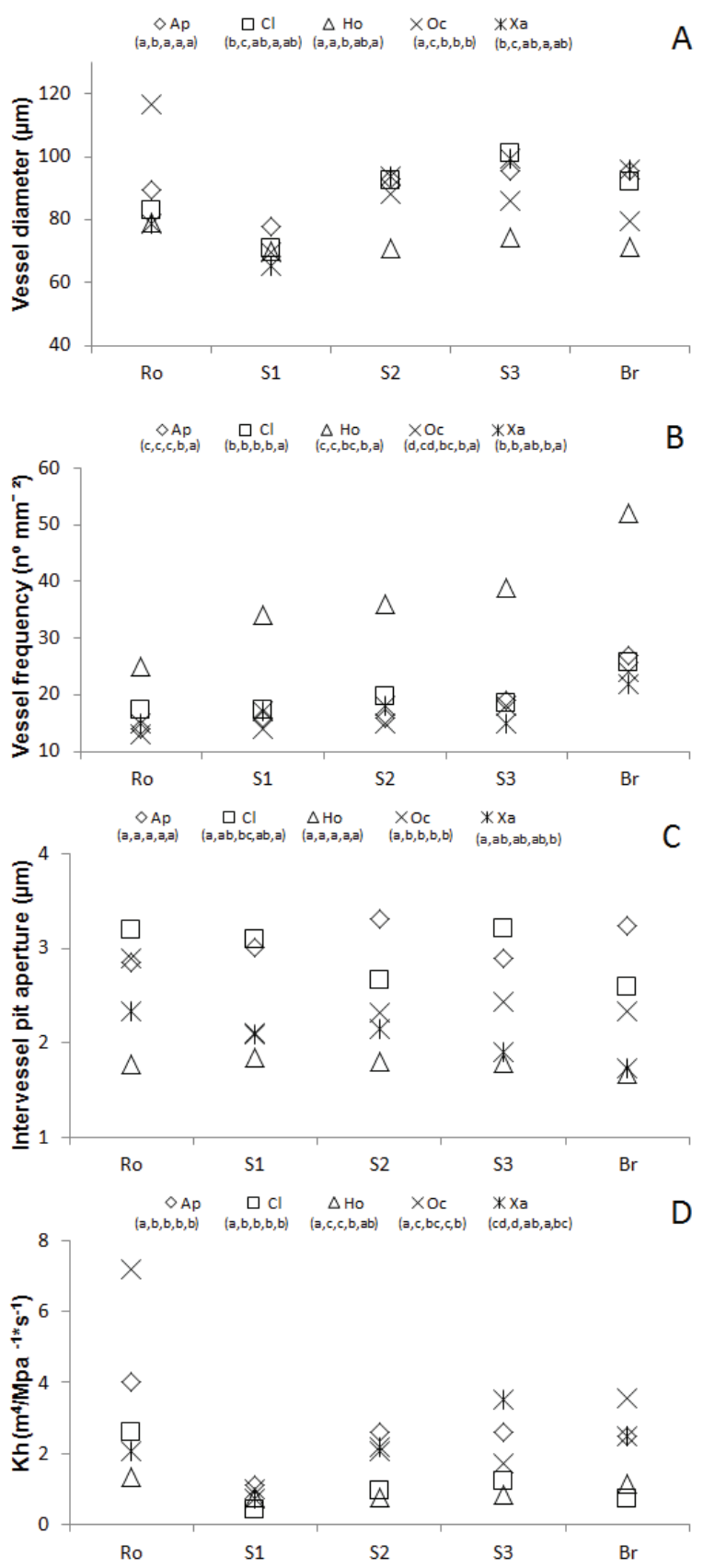

Figure 2. Variation in vessel features from root to the branch in five Brazilian Cerrado species. A) Vessel diameter. B) Vessel frequency. C) Intervessel pit aperture. D) Hydraulic conductivity $\left(\mathrm{K}_{\mathrm{h}}\right)$ $\mathrm{Ap}=$ Anadenanthera peregrina, $\mathrm{Cl}=$ Copaifera langsdorffi, $\mathrm{Ho}=$ Handroanthus ochraceus, Oc = Ocotea corymbosa and Xa $=$ Xylopia aromatica. Letters in brackets in each graph show the significant statistical variation in each species $(P<0.01$ by Tukey test $)$ and the sequence is always (root, stem1, stem2, stem3, branch).

Variación de las características de los vasos desde la raíz a la rama en cinco especies del Cerrado brasileño. A) Diámetro del vaso. B) Frecuencia de vaso. C) Abertura de las punteaduras intervasculares. D) Conductividad hidráulica. $\left(\mathrm{K}_{\mathrm{h}}\right) \mathrm{Ap}=$ Anadenanthera peregrina, $\mathrm{Cl}=$ Copaifera langsdorffii, $\mathrm{Ho}=$ Handroanthus ochraceus, $\mathrm{Oc}=$ Ocotea corymbosa y Xa = Xylopia aromatica. Las letras entre paréntesis en cada gráfico muestran la variación estadística significativa en cada especie $(P<0,01$ por la prueba de Tukey) y la secuencia es siempre la raíz, tronco1, tronco2, tronco3, rama. 


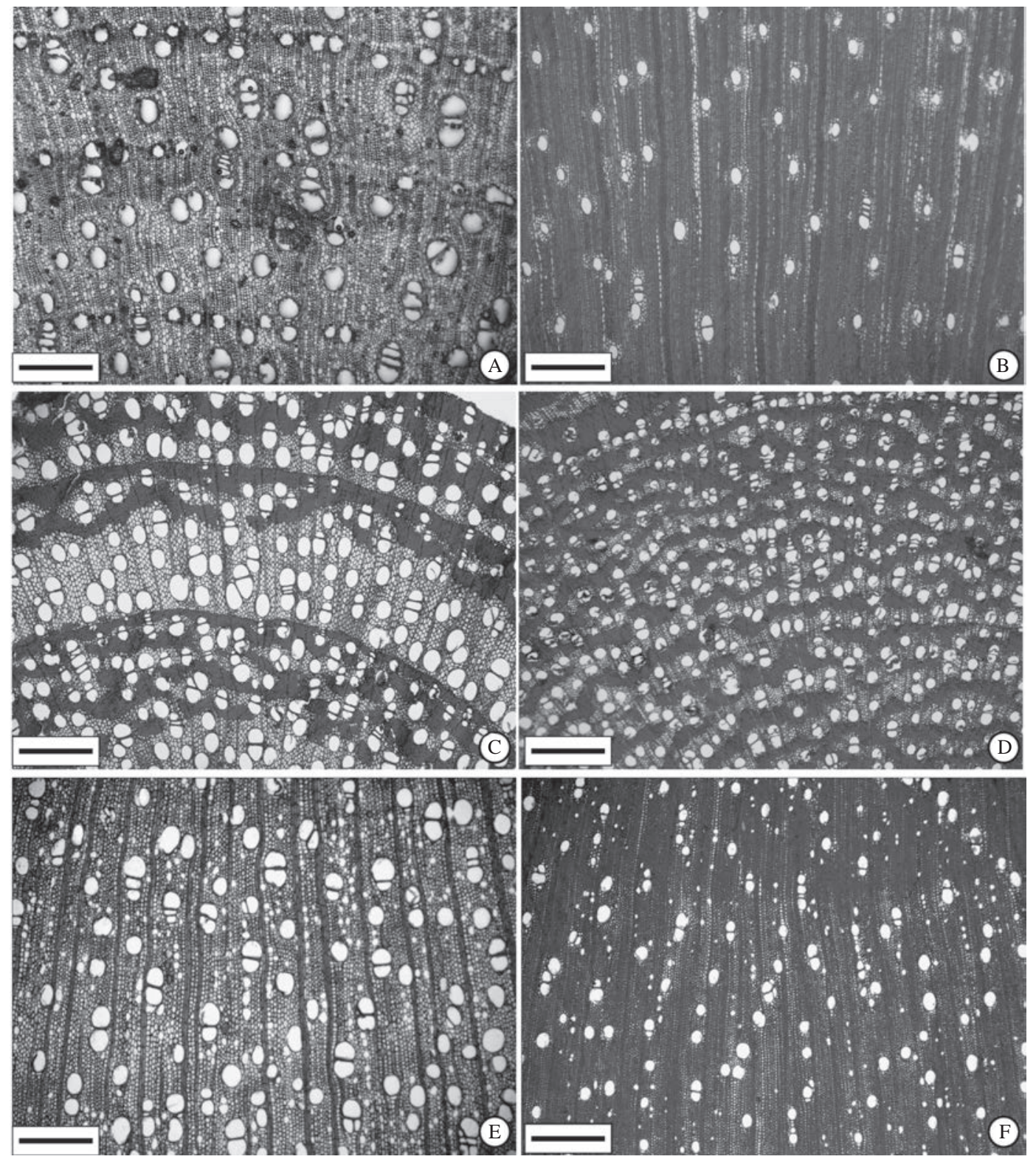

Figure 3. Transverse sections of root and stem base of Copaifera langsdorffi (A-B, respectively), Handroanthus ochraceus (C-D) and Ocotea corymbosa (E-F). Note the decrease in vessel diameter from root to stem base. Scale bars $=500 \mu \mathrm{m}$.

Secciones transversales de la raíz y la base del tronco de Copaifera langsdorffii (A-B, respectivamente), Handroanthus ochraceus (C-D) y Ocotea corymbosa (E-F) para ilustrar los resultados. Tenga en cuenta la disminución en el diámetro del vaso de la raíz a la base del tronco. Barras de escala $=500 \mu \mathrm{m}$.

Percentage of vessel grouping also varied among the species, highlighting the larger proportion of multiples of 4 or more vessels in the roots of $A$. peregrina and C. langsdorffii, and of $X$. aromatica, compared with the other axial positions. A lower proportion of solitary vessels and a higher proportion of multiples of 4 or more vessels are seen in $X$. aromatica, regardless of the position, compared with the other species (figure 4).

In C. langsdorffii, H. ochraceus and $O$. corymbosa, ray height decreased from the root to the stem base and from stem top (S3) to branch in A. peregrina and X. aromatica; although it increased from S3 to branch in $O$. corymbosa (figure 5A). Similarly, ray width increased from the root to the stem base in $C$. langsdorffii and $X$. aromatica; although it decreased in $O$. corymbosa. In $H$. ochraceus and $O$. corymbosa, decrease in width of the rays was noticed from S3 to branch (figure 5B). Ray frequency increased from the root to the stem base in A. peregrina, C. langsdorffii and O. corymbosa and decreased from S3 to the branch in Ocotea corymbosa (figure 5C). 


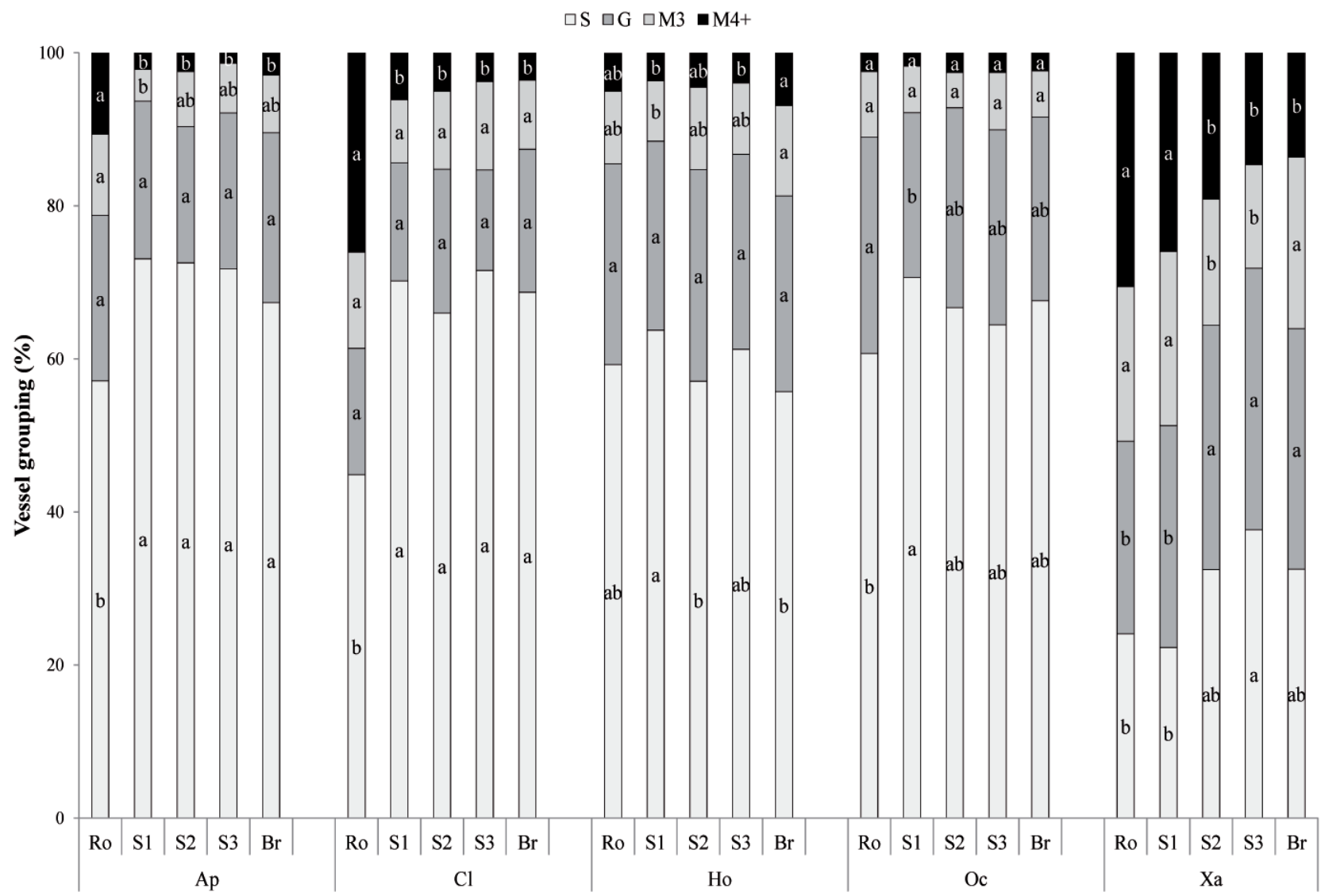

Figure 4. Variation in vessel grouping from root to branch in five Brazilian Cerrado species. Ap = Anadenanthera peregrina, $\mathrm{Cl}=$ Copaifera langsdorffi , Ho $=$ Handroanthus ochraceus, Oc $=$ Ocotea corymbosa and Xa $=$ Xylopia aromatica . Different letters under the species abbreviation indicate statistically significant differences at $P<0.01$ by Tukey test. Abbreviations: $\mathrm{S}=$ solitary vessel, $\mathrm{G}=$ geminate (multiples of 2), M3 = multiples of 3, M4+ = multiples of 4 or more vessels. Ro = root, $\mathrm{S} 1=$ Stem base, S2 = Middle of the stem, S3 = Stem top and Br. = Branch.

Variación en la agrupación de los vasos desde la raíz a la rama en cinco especies del Cerrado brasileño. Ap = Anadenanthera peregrina, $\mathrm{Cl}=$ Copaifera langsdorffi, $\mathrm{Ho}=$ Handroanthus ochraceus, $\mathrm{Oc}=$ Ocotea corymbosa y Xa $=$ Xylopia aromatica . Letras diferentes bajo la abreviatura de especies indican diferencias estadísticamente significativas a $P<0,01$ por la prueba de Tukey. Abreviaturas: $\mathrm{S}=$ vaso solitario, $\mathrm{G}=$ geminados (múltiplos de 2), M3 = múltiplos de 3, M4 + = múltiplos de 4 o más vasos Ro = raíz, S1 = Base del tronco, S2 = Medio del tronco, S3 = Parte superior del tronco y Br. = Rama.

Fiber length varied at different heights of the trees with longer fibers in different parts, depending on the species. More specifically, a decrease in fiber length was observed from the root to the stem base in A. peregrina and $O$. corymbosa, but an increase in fiber length is seen in $X$. aromatica. A. peregrina, $H$. ochraceus and $O$. corymbosa also exhibited a decrease in fiber length from $\mathrm{S} 3$ to branch and an increase was seen in C. langsdorffii (figure 6A). Fiber wall thickness also showed a wide range of variations depending on species. Fibers were thick-walled in root and stem top of A. peregrina, branch of C. langsdorffii, root of $H$. ochraceus, stem base and stem middle in O. corymbosa and stem top of $X$. aromatica (figure 6B). As compared with stem top and branch, a decrease in fiber wall thickness was noticed from the root to the stem base of A. peregrina and $H$. ochracreus; nevertheless it was increased in the root to the stem base region of O. corymbosa (figure 6B).

Dry biomass percentage is distributed differently among the species investigated. A higher percentage occurs in the middle of the stem of A. peregrina while no significant variation is observed in $C$. langsdorffii. Higher percentage of dry biomass is noticed in the root, stem base and branch for H. ochraceus, in the stem base and middle of the stem (S2) of $O$. corymbosa, and in the stem base of $X$. aromatica (figure $6 \mathrm{C}$ ).

Hydraulic conductivity correlated positively with vessel diameter $(0.70$ and $P<0.001)$ and negatively with vessel frequency $(0.39$ and $P=0.05)$ and fiber wall thickness $(0.41$ and $P=0.04$ ), while dry biomass correlated positively with fiber wall thickness $(0.51$ and $P=0.01)$. 

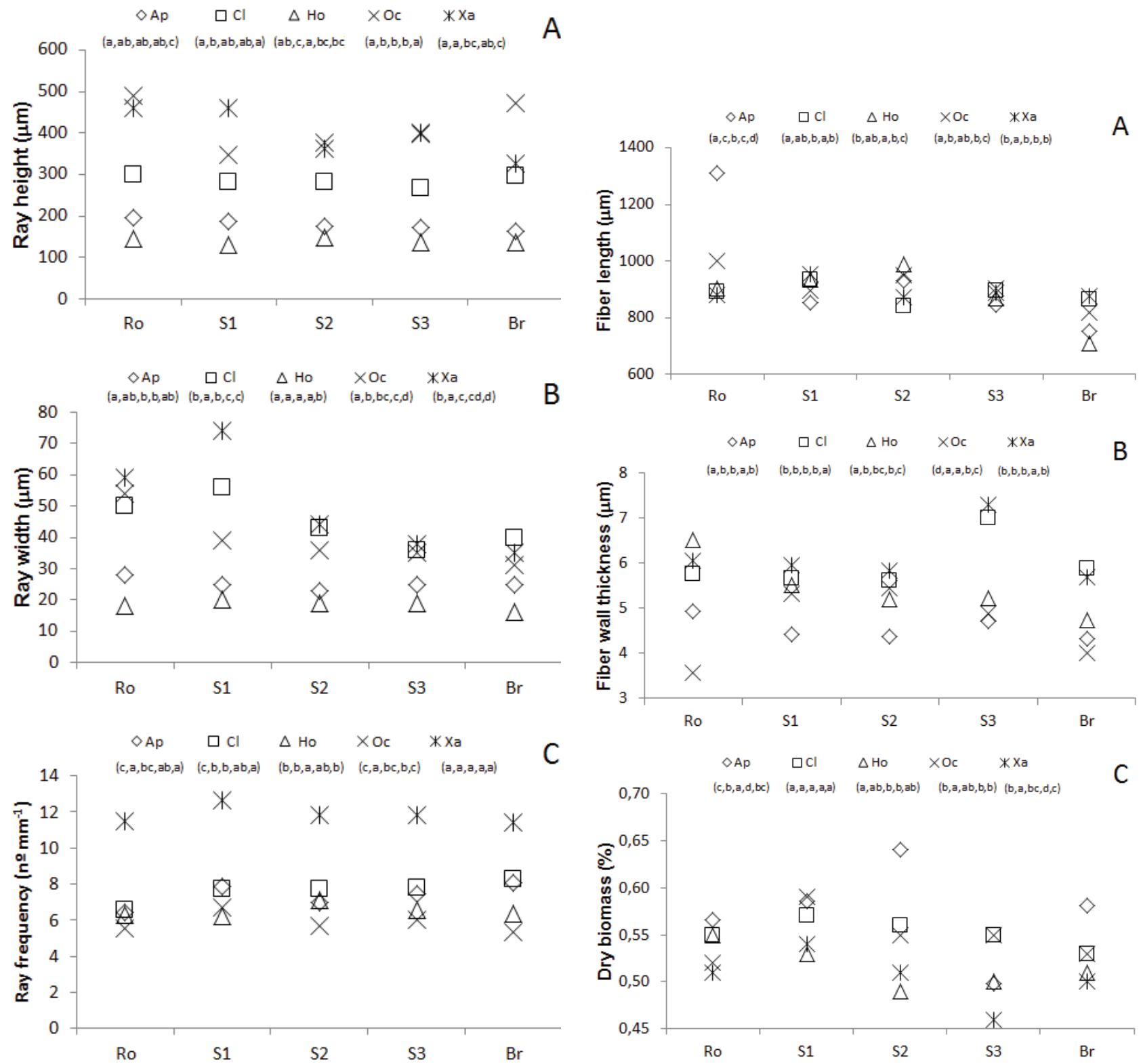

Figure 5. Variation in ray features from root to branch in five Brazilian Cerrado species. A) Ray height. B) Ray width. C) Ray frequency. Ap = Anadenanthera peregrina, $\mathrm{Cl}=$ Copaifera langsdorffi, $\mathrm{Ho}=$ Handroanthus ochraceus, $\mathrm{Oc}=$ Ocotea corymbosa and Xa = Xylopia aromatica. . Letters in brackets in each graph show the significant statistical variation in each species ( $P<0.01$ by Tukey test), and the sequence is always (root, stem 1 , stem2, stem3, branch).

Variación en las características de radios desde la raíz a la rama en cinco especies del Cerrado brasileño. A) Largo de los radios. B) Ancho de los radios. C) Frecuencia de los radios. Ap = Anadenanthera peregrina, $\mathrm{Cl}=$ Copaifera langsdorffii, $\mathrm{Ho}=$ Handroanthus ochraceus, Oc = Ocotea corymbosa y Xa = Xylopia aromatica . Las letras entre paréntesis en cada gráfico muestran la variación estadística significativa en cada especie ( $P<0,01$ por la prueba de Tukey) y la secuencia es siempre la raíz, tronco1, tronco2, tronco3, rama.

Figure 6. Variation in fiber features and dry biomass from root to branch in five Brazilian Cerrado species. A) Fiber length. B) Fiber wall thickness. C) Dry biomass percentage. Ap = Anadenanthera peregrina, $\mathrm{Cl}=$ Copaifera langsdorffii, $\mathrm{Ho}=$ Handroanthus ochraceus, Oc = Ocotea corymbosa and Xa = Xylopia aromatica. Letters in brackets in each graph show the significant statistical variation in each species $(P<0.01$ by Tukey test), and the sequence is always (root, stem 1 , stem 2 , stem 3 , branch).

Variación en las características de la fibra y la biomasa seca de la raíz a la rama en cinco especies Cerrado brasileño. A) Longitud de la fibra. B) Grosor de la pared de la fibra. C) Porcentaje de biomasa seca. $\mathrm{Ap}=$ Anadenanthera peregrina, $\mathrm{Cl}=$ Copaifera langsdorffii, $\mathrm{Ho}=$ Handroanthus ochraceus, Oc = Ocotea corymbosa y Xa = Xylopia aromatica. Las letras entre paréntesis en cada gráfico muestran la variación estadística significativa en cada especie $(P<0,01$ por la prueba de Tukey) y la secuencia es siempre la raíz, tronco1, tronco2, tronco3, rama. 


\section{DISCUSSION}

In the present investigation, the decrease in vessel diameter from the root to the stem base is accompanied by a decrease in hydraulic conductivity except in $X$. aromatica. Larger vessel diameter is said to be more efficient in water conductivity than smaller vessel diameter (Fan et al. 2012). Previous studies have reported a sharp drop in vessel diameter just above the branch junctions, termed "hydraulic bottlenecks" (Tyree and Zimmermann 2002). We did not observe any decrease in vessel diameter from stem top (S3) to branch in any of the species investigated, whereas hydraulic conductivity has been increased in $O$. corymbosa and decreased in X. aromatica, leading us to conclude that the presence of hydraulic bottlenecks is either absent or may be indistinct in Cerrado species, at least in young trees, such as those studied in the present investigation. The effect of all junction constrictions in a tree (studies with genus Thuja, Acer and Quercus) is unlikely to have much impact on water conductivity (Tyree and Zimmermann 2002). Therefore, if the bottleneck noticed in the stem base has no impact on water conductivity, in such case, the functional aspects of bottleneck remain an open question for debate. Vessel diameter is a crucial parameter in the identification of plant adaptation strategy to survive in specific environmental conditions (Sperry et al. 2006). Available literature indicates that the variation in vessel diameter is associated with habitat of the tree species and at various height of a tree (Anfodillo et al. 2013).

One possible explanation for narrower vessels in the stem base was offered by Aloni (2007). According to him, high auxin levels near young leaves (synthesis source) induce narrow vessels, while increasing distance from the source results in wider vessels. Another possible explanation is the segmentation hypothesis proposed by Tyree and Zimmermann (2002), according to which the decrease of vessels in the stem base would function the same way as the presence of narrower vessels at nodal regions to restrict embolism because the main stem represents the highest investment of the tree and should not, under any circumstances, be lost.

Functionally, narrower vessels at the stem base may contribute to water transport by pressure differences along vessels with higher resistance to water flow in narrower vessels. Such reasoning leads to the conclusion that this structural condition could regulate hydraulic conductivity in Brazilian Cerrado plants, or that it could be a universal standard. Pratt et al. (2010) measured hydraulic conductivity in nine species of Rhamnaceae. These authors hypothesized that the roots and leaves would be chief bottlenecks in the hydraulic pathway because of their extra-xylary pathways and root system that offered stronger resistance to water flow than that shown by shoots.

Our results suggest that stem-base wood ensures less risk of embolism by the presence of narrower vessels, while roots having vessels with larger diameter are more vulnerable. The relationship between conduit diameter and embolisms was nicely described by Hacke et al. (2005), in which they discussed the characteristics of pits and conduits and how they can prevent the formation of embolisms in wood.

Although a basipetal (from the top down) vessel diameter has been reported in many studies (Tyree and Zimmermann 2002). Petit and Crivellaro (2014) studied axial variation in Picea abies (L.) H. Karst., Fraxinus excelsior L. and Salix eleagnos Scop., and concluded that axial conduit widening seem to be a key feature of both xylem and phloem for long-distance transport of water and photosynthate. We emphasized the absence of any gradual decrease in vessel diameter from root to branches. According to Lintunen and Kalliokoski (2010), conduit tapering was closely accompanied by an increasing conduit frequency. The statements of Lintunen and Kalliokoski (2010), as cited above, may explain, at least partially, the lack of pattern for vessel frequency in the five species studied here. In our previous study on Eriotheca gracilipes (K. Schum.) A. Robyns, we found an inverse relationship between vessel diameter and vessel frequency from root to branch, with a decrease of vessel diameter toward the branch (Longui et al. 2012).

Hydraulic conductivity correlated positively with vessel diameter and negatively with vessel frequency. This result can be explained by the increase in hydraulic conductivity with increasing vessel diameter, since the vessel diameter was used to calculate conductivity and, according to Baas et al. (2004), there is a negative relation between vessel diameter and frequency. Negative correlation between hydraulic conductivity and fiber wall thickness may indicate that in wood regions, where conductivity is higher, there is less investment of the plant in mechanical resistance with thinner walls fibers.

Thus, bottleneck from the root to the stem base could impose a difficult flow to the stem base, which would be important in drought periods or in plants which are subjected to longer dryer periods after wet seasons. It should be noted that Assis City has two water deficit periods in April and August (figure 1). In contrast, bottlenecks could also increase flow resistance and improve conductance efficiency above the stem base. According to Bucci et al. (2008), Cerrado woody plants have deep roots that can get water even in the driest periods, which may account for the lack of significant seasonal variations in the transpiration of Cerrado trees. Moreover, these plants respond to a rigid stomatal control. According to Durigan et al. (2012), as well as our own field observation on 5 to 10 years old plants, their leaf longevity is different among the species. Anadenanthera peregrina and $H$. ochraceus are deciduous, while $C$. langsdorffii is brevi-deciduous, and O. corymbosa and $X$. aromatica are evergreen. Additionally, we also noticed that the length of the root varies among the species. Longer roots were noted in C. langsdorffii and H. ochraceus, though it is not possible to prove that root length helps to obtain deep water in dry periods. 
Ocotea corymbosa is the only species in which the intervessel pit aperture decreased from the root to the stem base, which indicates that this feature alone cannot clearly define hydraulic conductivity in the five species investigated.

If compared with stem positions, higher vessel grouping in roots of $A$. peregrina and $C$. langsdorffii may indicate a safer xylem to embolism, since water can flow into adjacent vessels when multiple vessels are embolized. Based on this theory, we suggest that $X$. aromatica has the safest wood among the five studied species because it has a higher proportion of multiple vessels at all levels in axial positions.

Our previous study showed a higher vessel grouping in branch and root of Eriotheca gracilipes (Longui et al. 2012). The roots of this plant were characterized by abundance of axial parenchyma cells with high capacity to store starch, a mechanism that would plausibly help in the recovery of embolized vessels (Clearwater and Goldstein 2005). It is therefore difficult to apply a single strategy to protect the vessels from embolism and cavitation. Parenchyma cells are important in storage and mobilization of carbohydrates during periods of low photosynthetic production. Carbohydrate especially starch is hydrolyzed into sugar; if that is translocated to vessels, it increases the osmotic potential and may play crucial role in pulling water, which may help in vessels recovery from air embolism.

In addition to hydraulic requirements, a smaller vessel diameter of the stem base is also related to mechanical requirements of the trees, because trees are tall and self-supporting plants, they need to resist the static loads, lateral wind forces or their own weight, with a perfectly stiff anchorage (Niklas 2000). From this point of view, the decrease in vessel diameter would tend to make denser and stronger wood since vessel lumens represent weak areas of xylem (Gartner and Meinzer 2005). This information corroborates Christensen-Dalsgaard et al. (2007) findings on six species of tropical trees; they stated that the smallest vessels and the lowest vessel frequency were found in the parts of the trees subjected to the highest stress or strain. Therefore, there is a trade-off between conductivity and stiffness or strength with changes in vessel anatomy in response to mechanical loading, suggesting that anatomical alterations occur in response to mechanical strain. According to Rowe and Speck (2005), the hydraulic and mechanical requirements are evolutionarily related to each other.

Wood will be stronger in the radial direction as compared with tangential one, depending on the proportion of rays; essentially because rays, according Mattheck and Kubler (1995), "lock" growth rings preventing sliding. Burgert et al. (1999) and Reiterer et al. (2002) emphasize the biomechanical role of rays. Longui et al. (2016) studied shear strength parallel to grain with distinct ray orientation on four Brazilian wood species (Balfourodendron riedelianum (Engl.) Engl., Dipteryx alata Vogel, Myracrodruon urundeuva Allemão and Peltophorum dubium (Spreng.) Taub.). They did not observe statistical differences among ray orientations-- perpendicularly, parallel or diagonal-- regarding the shear plane, and despite higher rays occur in specimens with high and medium levels of shear strength. Other ray dimensions and frequency did not show any evidence pattern when related to shear strength. In the present study, there was variation among height, width and frequency of rays from the root to the stem base, a key region of the stem in terms of biomechanical role. We noticed a decrease in ray height in $C$. langsdorffii, $H$. ochraceus and $O$. corymbosa, and in ray width in $O$. corymbosa; however an increase in ray width in $C$. langsdorffii and $X$. aromatica; an increase in ray frequency in A. peregrina, $C$. langsdorffii and $O$. corymbosa. These structures should contribute to mechanically weak wood, since loads such as those caused by wind velocity acting on the canopy will increase toward the tree base, and roots can anchor in the soil (Niklas 2000), resulting in a high mechanical requirement for the stem base. The plants that we studied are young and relatively thin and occurred in a flat area and open physiognomy with vegetation composed of sparsely distributed trees allowing for wind incidence between them. Therefore, structural changes are important to prevent trees from breaking by the action of wind and heavy rain.

Fibers occur in higher proportion in angiosperm wood; they are specialized cells in mechanical support. Therefore, it is expected that variations in their dimensions, especially in wall thickness, would have significant impacts on mechanical properties. Studies show that fiber features impact on the mechanical properties of composite materials, e.g. Lee et al. (2001). Others related thicker walls (Quilhó et al. 2006) and longer fibers (Butterfield et al. 1993) to higher wood density, a physical property directly related to mechanical properties and resistance. However, we did not find a direct relation of wall thickness and fiber length with higher resistance, since by variations found in the five species, it was not possible to establish a pattern, because only in $O$. corymbosa there are thicker wall fibers at the base and middle stem, and only in $X$. aromatica there are longer fibers at stem base, region where higher mechanical requirement is expected. The pattern of variation found in the transition between root and stem base suggests that mechanical requirements are supplied by the association among fibers, vessels and rays. Lintunen and Kalliokoski (2010) reported that trees adjust micro- and macrostructure to maximize water transport, prevent embolism and ensure mechanical safety. With the exception of $C$. langsdorffii, the only result shared among the four other species was the presence of fibers with thinner walls in the branch compared with stem top (S3) possibly due to juvenile wood, which is characterized by thin cell walls.

We observed that dry biomass percentage was distributed differently along the plant; however it correlated positively with fiber wall thickness, a result expected in some way, since fibers are the cells present in larger numbers compared with vessels and parenchyma cells; therefore, an increase in fiber wall thickness directly influences dry biomass percentage. 


\section{CONCLUSIONS}

In general terms, our hypothesis that there is a pattern in hydraulic architecture of xylem towards root-branch trees, regardless of species, to optimize the potential of water conductivity was confirmed.

Our results suggest that stem base protects the xylem of the main stem against the risk of embolism due to the presence of narrower vessels. The presence of hydraulic bottlenecks is evident in the transition from the root to the stem, but the same cannot be said for the transition from stem to branch, especially since this trait was only observed in $X$. aromatica. The higher proportion of multiple vessels in the roots of $A$. peregrina, $C$. langsdorffii, and in the root and stem base in $X$. aromatica seems to indicate a tendency toward a more important investment in safer wood in the roots compared to the stem. Pit apertures showed no clear pattern, though this feature does not clearly influence conductivity along the tree. Results of dimensions and frequency of rays, fibers and dry biomass percentage do not clearly indicate how variations in these cells have an impact on mechanical strength on the wood of tree species studied in the present investigation. However, a decrease in vessel diameter from the root to the stem base, besides reducing hydraulic conductivity, may also impact mechanical strength by reducing empty spaces (vessel lumen).

\section{ACKNOWLEDGEMENT}

We are grateful to the Conselho Nacional de Desenvolvimento Científico e Tecnológico - CNPq "National Counsel of Technological and Scientific Development" for grants to Laura de Araújo Alves (108958/2010-8) and Caroline Bianca do Nascimento (108966/2010-0), and we are especially grateful to Sonia Godoy Campião for laboratory assistance. Authors are also thankful for the reviewers for their critical suggestions on the previous version of the manuscript.

\section{REFERENCES}

Aloni R. 2007. Phytohormonal mechanisms that control wood quality formation in young and mature trees. In Entwistle K, P Harris, J Walker eds. The Compromised Wood Workshop. Christchurch, New Zealand. The Wood Technology Research Centre, University of Canterbury. p. 1-22.

Anfodillo T, G Petit, A Crivellaro. 2013. Axial conduit widening in woody species: a still neglected anatomical pattern. IAWA Journal 34(4): 352-364.

Baas P, FW Ewers, SD Davis, EA Wheeler. 2004. Evolution of xylem physiology. In Poole I, Hemsley A. eds. Evolution of Plant Physiology. London, UK. Elsevier Academic Press. p. 273-295. (Linnaean Society Symposium Series)

Berlyn GP, JP Miksche. 1976. Botanical Microtechnique and Cytochemistry. Ames, Iowa, United States of America. The Iowa State University Press. 326 p.

Bucci SJ, FG Scholz, G Goldstein, FC Meinzer, AC Franco, Y
Zhang, G Hao. 2008. Water relations and hydraulic architecture in Cerrado trees: adjustments to seasonal changes in water availability and evaporative demand. Brazilian Journal of Plant Physiology 20(3): 233-245.

Burgert I, A Bernasconi, D Eckstein. 1999. Evidence for the strength function of rays in living trees. Holz als Roh- und Werkstoff 57(5): 397-399.

Butterfield RP, RP Crook, R Adams, R Mol'ris. 1993. Radial variation in wood specific gravity, fibre length and vessel area for two central American hardwoods: Hyeronima alchorneoides and Vochysia guatemalensis: natural and plantation grown trees. Iawa Journal 14(2): 153-161.

CEPAGRI (Centro de Pesquisas Meteorológicas e Climáticas Aplicadas a Agricultura, BR). 2015. Clima dos Municípios Paulistas. Consulted 23 oct. Available in http://www. cpa.unicamp.br/outras-informacoes/clima-dos-municipiospaulistas.

Choat B, A Cobb, S Jansen. 2008. Structure and function of bordered pits: New discoveries and impacts on whole plant hydraulic function. New Phytologist 177(3): 608-626.

Christensen-Dalsgaard KK, M Fournier, AR Ennos, AS Barfod. 2007. Changes in vessel anatomy in response to mechanical loading in six species of tropical trees. New Phytologist 176(3): 610-622.

Clearwater MJ, G Goldstein. 2005. Embolism repair and long distance water transport. In Holbrook NM, Zwienniecki MA eds. Vascular transport in plants. Amsterdam, Netherlands. Elsevier. p. 375-400.

Durigan G, ACG Melo, J Brewer. 2012. The root to shoot ratio of trees from open-and closed-canopy cerrado in southeastern Brazil. Plant Ecology \& Diversity 5(3): 333-343.

Fan ZX, SB Zhang, GY Hao, JW Ferry Slik, KF Cao. 2012. Hydraulic conductivity traits predict growth rates and adult stature of 40 Asian tropical tree species better than wood density. Journal of Ecology 100(3): 732-741.

Gartner BL, F Meinzer. 2005. Structure function relationships in sapwood water transport and storage. In Holbrook NM, MA Zwienniecki eds. Vascular transport in plants. Amsterdam, Netherlands. Elsevier. p. 307-332.

Gasson PE. 1987. Some implications of anatomical variations in the wood of pedunculate oak (Quercus robur L.), including comparisons with common beech (Fagus sylvatica L.). IAWA Bulletin 8(2): 149-166.

Goulart SL, Marcati CR. 2008. Anatomia comparada do lenho em raiz e caule de Lippia salviifolia Cham. (Verbenaceae). Revista Brasileira de Botânica 31(2): 263-275.

Hacke UG, JS Sperry, J Pittermann. 2005. Efficiency versus safety tradeoffs for water conduction in angiosperm vessels versus gymnosperm tracheids. In Holbrook NM, MA Zwienniecki eds. Vascular transport in plants. Amsterdam, Netherlands. Elsevier. p. 333-354.

IAWA (International Association of Wood Anatomists, NL). 1989. IAWA list of microscopic features for hardwood identification. IAWA Bulletin 10: 219-332.

Lee BJ, AG McDonald, B James. 2001. Influence of fiber length on the mechanical properties of wood-fiber/polypropylene prepreg sheets. Material Research Innovations 4(2):97-103.

Lintunen A, T Kalliokoski. 2010. The effect of tree architecture on conduit diameter and frequency from small distal roots to branch tips in Betula pendula, Picea abies and Pinus sylvestris. Tree Physiology 30(11): 1433-1447. 
Longui EL, RABG Silva, D Romeiro, IL Lima, SMB Florsheim, ACG Melo. 2012. Root-branch anatomical investigation of Eriotheca gracilipes young trees: a biomechanical and ecological approach. Scientia Forestalis 93(1): 23-33.

Longui EL, GT Pires, AW Ballarin, JAR Machado. 2016. Shear strength parallel to grain with distinct ray orientation on four Brazilian wood species. European Journal of Wood and Wood Products. doi:10.1007/s00107-016-1129-8

Machado SR, RA Rodella, V Angyalossy, CR Marcati. 2007. Structural variations in root and stem wood of Styrax (Styracaceae) from Brazilian forest and cerrado. IAWA Journal 28(2): 173-188.

Mattheck C, H Kubler. 1995. Wood - The internal optimization of trees. Berlin, Germany. Springer-Verlag. 129 p.

Niklas K. 2000. Plant Biomechanics: an engineering approach to plant form and function. Chicago, United States of America. University of Chicago Press. 607 p.

Oliveira-Filho AT, Ratter JA. 2002. Vegetation physiognomies and woody flora of the cerrado biome. In Oliveira-Filho AT, Marquis RJ eds. The cerrados of Brazil: ecology and natural history of a Neotropical savanna (P.S.). New York, USA. Columbia University Press. p. 91-120.

Olson ME, JA Rosell. 2013. Vessel diameter-stem diameter scaling across woody angiosperms and the ecological causes of xylem vessel diameter variation. New Phytologist 197(4): 1204-1213.

Palhares D, de Paula JE, Pereira LAR, Silveira CES. 2007. Com- parative wood anatomy of stem, root and xylopodium of Brosimum gaudichaudii (Moraceae). Iawa Journal 28(1): 83-94.

Petit G, A Crivellaro. 2014. Comparative axial widening of phloem and xylem conduits in small woody plants. Trees: Structure and Function 28(3): 915-921.

Pratt RB, GB North, AL Jacobsen, FW Ewers, SD Davis. 2010. Xylem root and shoot hydraulics is linked to life history type in chaparral seedlings. Functional Ecology 24(1): 70-81.

Quilhó T, I Miranda, H Pereira. 2006. Within-tree variation in wood fibre biometry and basic density of the urograndis eucalypt hybrid (Eucalyptus grandis x E. urophylla). Iawa Journal 27(3): 243-254.

Reiterer A, I Burgert, G Sinn, S Tschegg. 2002. The radial reinforcement of the wood and its implication on mechanical and fracture mechanical properties - a comparison between two tree species. Journal of Materials Science 37(5): 935-940.

Rowe N, T Speck. 2005. Plant growth forms: an ecological and evolutionary perspective. New Phytologist 166(1): 61-72.

Scholz A, M Klepsch, Z Karimi, S Jansen. 2013. How to quantify conduits in wood? Frontiers in Plant Science 4: 1-11.

Sperry JS, UG Hacke, J Pittermann. 2006. Size and function in conifer tracheids and angiosperm vessels. American Journal of Botany 93(10): 1490-1500.

Tyree MT, MH Zimmerman. 2002. Xylem structure and the ascent of sap. New York, United States of America. Springer. $283 \mathrm{p}$. 
